\title{
ANALYSIS OF CLINICAL AND MOLECULAR GENETIC CHARACTERISTICS OF WISKOTT-ALDRICH SYNDROME AND X-LINKED THROMBOCYTOPENIA
}

\author{
Doina TURCAN ${ }^{1}$, Lucia ANDRIES ${ }^{2}$, Alexandr DORIF ${ }^{1,2}$, Victoria SACARA ${ }^{1,2}$ \\ 1 Institute of Mother and Child, Republic of Moldova \\ 2Nicolae Testemitanu State University of Medicine and Pharmacy, Republic of Moldova
}

Corresponding author: Sacara Victoria, e-mail: victoriasacara@hotmail.com

DOI: $10.38045 /$ ohrm.2021.3.10

CZU: [616.155.294+612.017.1]-053.2:575.224

Keywords: Wiskott Aldrich syndrome, $X$ linked thrombocytopenia, immunodeficiency.

Cuvinte cheie: sindromul Wiskott-Aldrich, trombocitpenie $X$-linkată, imunodeficiență.
Introduction. Wiskott-Aldrich syndrome is a rare X-linked disorder characterized by microthrombocytopenia, eczema, and recurrent infections. It is caused by mutations of the WAS gene which encodes the WAS protein (WASp) - a key regulator of actin polymerization in hematopoietic cells. Mutations within the WASp gene result in a wide heterogeneity of clinical disease, ranging from 'classical WAS' to mild asymptomatic thrombocytopenia (X-linked thrombocytopenia [XLT]]), or congenital neutropenia (X-lined neutropenia [XLN]).

Case presentation. This present paper reports a phenotypical and laboratory description of two children diagnosed with WAS and one child diagnosed with XLT. The first case was a six months old male with septicemia, thrombocytopenia, eczema and petechial rash. The second case was a 2 years old boy presenting with complaints of recurrent infections, eczema and thrombocytopenia with small platelet size. The third case was a 16 years old boy who presented with thrombocytopenia and recurrent sinopulmonary infections.

Conclusions. Due to a wide spectrum of clinical findings, the diagnosis of WAS/XLT should be considered in any male patient presenting with petechiae, bruises, and congenital or early-onset thrombocytopenia associated with small platelet size.

ANALIZA CARACTERISTICILOR CLINICE SI MOLECULAR-GENETICE ALE SINDROMULUI WISKOTT-ALDRICH ȘI TROMBOCITOPENIA X-LINKATĂ

Introducere. Sindromul Wiskott-Aldrich este o afecțiune rară X-linkată, caracterizată prin microtrombocitopenie, eczeme și infecții recurente. Acesta este cauzat de mutații ale genei WAS, care codifică proteina WAS (WASp) - un regulator cheie al polimerizării actinei în celulele hematopoietice. Mutațiile din gena WASp generează o eterogenitate largă a bolii clinice, variind de la „WAS clasic” la trombocitopenie asimptomatică ușoară (trombocitopenie X-linkată [XLT]) sau la neutropenie congenitală (neutropenie X-linkată [XLN]).

Prezentarea cazului. Este raportată descrierea, fenotipică și de laborator, a doi copii diagnosticați cu WAS și a unui copil diagnosticat cu XLT. În primul caz, un băiat în vârstă de șase luni, cu septicemie, trombocitopenie, eczemă și erupții de tip peteșii. În al doilea caz, un băiat de 2 ani, care a prezentat acuze de infecții recurente, eczemă și trombocitopenie, cu dimensiune mică a trombocitelor. Iar în al treilea caz, un băiat de 16 ani, care s-a adresat cu acuze de infecții sinopulmonare recurente și trombocitopenie.

Concluzii. Datorită spectrului larg de manifestări clinice, diagnosticul WAS/XLT trebuie luat în considerare la orice pacient de sex masculin, care prezintă erupții de tip peteșii, echimoze și trombocitopenie congenitală sau cu debut precoce, asociată cu o dimensiune mică a trombocitelor. 


\section{INTRODUCTION}

The Wiskott-Aldrich syndrome (WAS, OMIM 301000) is a rare X-linked immunodeficiency syndrome originally described by Dr. Alfred Wiskott in 1937 and Dr. Robert Aldrich in 1954 as a familial disease, characterized by the classic triad of severe immunodeficiency, microthrombocytopenia, and eczema. The incidence of WAS is estimated at between 1 in $10^{5}$ and 1 in $10^{6}$ cases per live birth and WAS makes up approximately 3\% of all Primary Immunodeficiencies Disorders in the European Society for Immunodeficiency registry (1).

The gene responsible for WAS is located on the short arm of the X chromosome at Xp11.22p11.23. The WAS gene encodes the WAS protein (WASp), which is a cytosolic multidomain 502amino acid protein expressed within the cytoplasm of nonerythroid hematopoietic cells. WASp is involved in actin polymerization and associated coupling of receptor engagement, signaling events, and cytoskeletal rearrangement (2). $\mathrm{Mu}-$ tations within the WASp gene result in a wide heterogeneity of clinical disease, ranging from 'classical WAS', where babies present in the first year of life with a severe persistent thrombo-cytopenia, opportunistic and increased frequency of respiratory tract infections and early development of autoimmunity (3), to mild asymptomatic thrombocytopenia (X-linked thrombocytopenia [XLT]), or congenital neutropenia (X-lined neutropenia [XLN]) (1). X-linked thrombocytopenia (XLT), shares similar bleeding risk from thrombocytopenia but is not associated with other significant clinical features and is generally managed conservatively (4).

In WASP-deficient cells, the formation of the Immunological Synapse (IS) in T cells and T Cell Receptor (TCR)-dependent activation, the cyto-toxic activity of CD8+ T cells and Natural Killer (NK) cells and the suppressor activity of Naturally occurring Regulatory $\mathrm{T}$ (nTreg) cells are all impaired. Motility, adhesion and migration of B cells are also defective. Additionally, the lack of WASP affects podosome formation, motility and $\mathrm{T}$ cell priming in Dendritic Cells, as well as podosome and phagocytic cup formation in macrophages (5).

Low number of platelets and thrombocytopenia are universal features of WAS, usually present in the first year of life and typically causing pete- chiae, easy bruising, spontaneous or prolonged bleeding. Life-threatening bleeding episodes, particularly gastrointestinal or intracranial bleeding, have been reported in $10-30 \%$ of patients (4). Patients with WAS are at a higher risk of developing autoimmunity, the most frequent being hemolytic anemia (36\%), followed by vasculitis (including cerebral vasculitis; 29\%), arthritis (29\%), neutropenia (25\%), inflamma-tory bowel disease (9\%), and IgA nephropathy (3\%). Henoch-Schönlein-like purpura, dermatomyositis, recurrent angioedema, and uveitis have also been reported in some patients (5). Furthermore, WAS patients often develop hematological malignancies often associated with Epstein-Barr virus infection and of poor prognosis (6). The tumor incidence in WAS is estimated to be $13-22 \%$ with a mean age of onset of 9.5 years and with poor prognosis. WAS patient tumors include nonHodgkin lymphoma, EBV positive and EBV negative lymphoma, Hodgkin lymphoma, Burkitt lymphoma, and less frequently myelodysplasia, acute lymphoblastic leukemia, myelomonocytic leukemia, and nonhematopoietic malignancies $(7,8)$.

The immunodeficiency in WAS involves T cells, and is associated with both quantitative and qualitative defects in $\mathrm{T}$ cells. Humoral immune responses are abnormal: patients with WAS exhibit variable levels of serum IgM, normal to high levels of serum IgA, and high levels of serum IgD, IgG, and IgE (2). Despite the presence of normal numbers of neutrophils, monocytes, and other phagocytes, functional abnormalities may also be present in patients with WAS. Chemotaxis, the initiation of degranulation, the formation of a functional respiratory burst, and antibody-medi-ated phagocytosis may be impaired in patients with WAS (9).

With regard to treatment, hematopoietic stem cell transplantation (HSCT) is the current accepted curative approach for patients with WAS. Patients with WAS, who undergo unrelated donor HSCT at younger ages (less than 5 years of age), have outcomes that are comparable to those associated with the use of matched-sibling donor HSCT (3). At present, gene therapy in WAS patients offers remarkable possibilities. The first gene therapy study in WAS used a $\gamma$-retroviral vector, with WASp expression driven via the viral promoter (10). Restoration of $\mathrm{T}$ proliferative responses, polyclonal T-cell repertoires, natural killer cell cytotoxicity and antibody responses to vaccination 
were demonstrated post treatment, and platelet counts were either within the normal range $(43 \%)$ or significantly higher than pregene therapy (57\%) (11). Another trial used a self-inactivating lentivirus vector for WAS gene correction in which a $1.6 \mathrm{~kb}$ fragment of the proximal promoter of the WAS gene is used to express the fulllength coding sequence of the human WAS gene in cells of the hematopoietic lineage. Consequently, there has been an improvement at 24 months in eczema, the frequency and severity of infections, bleeding tendency, autoimmunity, reduction in disease-related days of hospitalization and improvement in immunological and haematological parameters $(12,13)$. This vector has also been applied to adult WAS patient (14).

\section{CASE PRESENTATION}

Patients were referred to the Human Molecular Genetics Laboratory at the Institute of Mother and Child, for genetic counselling. In order to establish the diagnosis, the WAS clinical scoring system was used, which ranges between 0 and 5 , including the presence of thrombocytopenia, eczema, immunodeficiency, autoimmunity, and malignancy. Immunological investigations were performed in order to identify changes suggestive of the presence of the disease in suspected patients. The number of T-cell receptor excision circle (TREC)/kappa-deleting recombination excision circle (KREC) copies were quantified by qPCR and were related to the albumin control gene.

The first case was a 6-month-old male patient with a WAS score equal to 3 which is considered "classic" WAS. He was the first child born from nonconsanguineous parents. He was admitted to the IMSP Institute of Mother and Child with septicemia, thrombocytopenia, eczema and petechial rash. The patient also presented with restraint in physical development (petty malnutrition) and motor-hypotonicity. Besides those mentioned above, the patient also revealed respiratory insufficiency, cytomegalovirus hepatitis, signs of cardio-circulatory insufficiency, disseminated intravascular coagulation. During the hospitalization, the condition of the child was severe, presenting cardio-circulatory insufficiency, marked hepatomegaly, myotonia, and psychomotor retardation. Quantitative serum immunoglobulin tests detected a low serum level of $\operatorname{IgM}(0.3 \mathrm{~g} / \mathrm{L})$ and $\operatorname{IgA}$ $(0.2 \mathrm{~g} / \mathrm{L})$, elevated IgE $(767.6 \mathrm{kU} / \mathrm{L})$, low level of
CD4(+) T cells (9\%), elevated CD8(+) T cells (59\%). Treatment is directed mainly at control of bleeding through transfusions of blood and platelets, and control of infections with antibiotics and Immunoglobulin replacement.

The second case was a 2-year-old boy presenting with complaints of recurrent infections, eczema and thrombocytopenia with small platelet size (WAS clinical score - 3). The mother of the patient had a brother who died at a young age and no clear diagnosis was made at that time. Analysis of serum immunoglobulins revealed a low serum level of IgM $(0.2 \mathrm{~g} / \mathrm{L})$, normal $\operatorname{IgA}(1.39 \mathrm{~g} / \mathrm{L})$ and normal IgG (7.18 g/L), low level of CD3(+) (63\%), low level of $\mathrm{CD} 4(+) \mathrm{T}$ cells (32\%), elevated CD8(+) T cells (28\%), elevated CD16(+) (32\%). Quantification of TREC/KREC copies showed low TREC and KREC levels.

The third case was a 16-year-old boy who presented with thrombocytopenia and recurrent sinopulmonary infections. In the present case, the WAS clinical score was 2 , which rather suggested the presence of XLT. Immunological investigations indicated a normal immunoglobulin profile, low level of CD4(+) T cells $(29,8 \%)$ and elevated CD8(+) T cells $(36,6 \%)$. TREC and KREC copy counts revealed low TREC levels while KREC level was within the normal range.

\section{DISCUSSIONS}

During the period 2016-2020, WAS was clinically suspected in 5 patients, all of Caucasian ethnicity. The diagnosis was genetically confirmed in 3 patients.

Diagnosing Wiskott-Aldrich syndrome can be difficult and is often overlooked or confused with other more common conditions. The presence of family history makes the diagnosis easier. The mean age at the time of diagnosis is 24 months in patients whose family members are unaffected by this syndrome previously (15).

For the purpose of performing the genetic test, genomic DNA was isolated from peripheral blood leukocytes by using the Salting-out method. In order to examine mutations on the WAS gene, direct sequencing was performed on the ABI $3500 \mathrm{DX}$ Genetic Analyzer (Applied Biosystems) for all 12 coding regions of the WAS gene listed in Table 1. Data were analyzed using the bioinformatic software "Sequencing Analysis Software v6.0". 
Table 1. Primer sequences for Sanger sequencing $(16,17,18)$.

\begin{tabular}{|c|c|c|c|}
\hline Primer & $\begin{array}{l}\text { Forward/ } \\
\text { Reverse }\end{array}$ & Sequence $\left(5^{\prime}-3^{\prime}\right)$ & $\begin{array}{l}\text { Product length } \\
\text { (bp) }\end{array}$ \\
\hline \multirow{2}{*}{$\begin{array}{l}\text { WAS gene } \\
\text { Exon } 1\end{array}$} & Forward & GGTCTAAGCAGTCAAGTGG & \multirow[t]{2}{*}{498} \\
\hline & Reverse & GGAAGGGTGGATTATGACG & \\
\hline \multirow{2}{*}{$\begin{array}{l}\text { WAS gene } \\
\text { Exon } 2\end{array}$} & Forward & TACCCCTGACCAGACTCCAC & \multirow[t]{2}{*}{237} \\
\hline & Reverse & GGTTTGGGGGTTGAGAACT & \\
\hline \multirow{2}{*}{$\begin{array}{l}\text { WAS gene } \\
\text { Exon } 3\end{array}$} & Forward & СТСССАСССТАСАССТСТСС & \multirow[t]{2}{*}{164} \\
\hline & Reverse & TTCССАТСТССТСТCСАСАС & \\
\hline \multirow{2}{*}{$\begin{array}{l}\text { WAS gene } \\
\text { Exon } 4\end{array}$} & Forward & CTCACTTGGGGTGTGGAGAG & \multirow[t]{2}{*}{219} \\
\hline & Reverse & АССТCTGCССААСТTССТTТ & \\
\hline \multirow{2}{*}{$\begin{array}{l}\text { WAS gene } \\
\text { Exon } 5\end{array}$} & Forward & AAGGAATCAGAGGCAAAGTG & \multirow[t]{2}{*}{248} \\
\hline & Reverse & GGGAAGATGGAATGTGTAGA & \\
\hline \multirow{2}{*}{$\begin{array}{l}\text { WAS gene } \\
\text { Exon } 6\end{array}$} & Forward & GTGGCAGGGCTGTGATAACT & \multirow[t]{2}{*}{223} \\
\hline & Reverse & GCTCGTCCATCCACATACCT & \\
\hline \multirow{2}{*}{$\begin{array}{l}\text { WAS gene } \\
\text { Exon } 7\end{array}$} & Forward & ТАССТССАТGACСАТССААСА & \multirow[t]{2}{*}{380} \\
\hline & Reverse & CСATCCTTCCATTCACTCAGC & \\
\hline \multirow{2}{*}{$\begin{array}{l}\text { WAS gene } \\
\text { Exon 8-9 }\end{array}$} & Forward & CAAGAGGTTTCACTATGAAGG & \multirow[t]{2}{*}{534} \\
\hline & Reverse & GCGTATCTTAGCTATGAGCTGC & \\
\hline \multirow{2}{*}{$\begin{array}{l}\text { WAS gene } \\
\text { Exon } 9\end{array}$} & Forward & CCTGGCCTTTTTCCTCCT & \multirow[t]{2}{*}{208} \\
\hline & Reverse & AGAAGGGAGCGTATGGAAGC & \\
\hline \multirow{2}{*}{$\begin{array}{l}\text { WAS gene } \\
\text { Exon } 10\end{array}$} & Forward & GCTTCAGTCAGGAGTTGGTC & \multirow[t]{2}{*}{580} \\
\hline & Reverse & TCCTGACTTAGACGGGACAC & \\
\hline \multirow{2}{*}{$\begin{array}{l}\text { WAS gene } \\
\text { Exon } 11\end{array}$} & Forward & GGGAGAAATGCTCCTTTCC & \multirow[t]{2}{*}{291} \\
\hline & Reverse & GTTAATGCTGTCAAACAGATG & \\
\hline \multirow{2}{*}{$\begin{array}{l}\text { WAS gene } \\
\text { Exon } 12\end{array}$} & Forward & TTAACCAGACAGGAAGCAAT & \multirow[t]{2}{*}{593} \\
\hline & Reverse & CTTGAGTGAAGAGAACTGAGA & \\
\hline
\end{tabular}

Genetic analysis of WAS gene was performed in the first patient, and subsequently in the patient's mother. The direct sequencing analysis showed A-to-G transition at complementary nucleotide 274 (c.274-2 A>G), located in intron 2 (fig. 1a). Molecular analysis of the WAS gene performed in the patient's mother revealed no mutation. Thus, taking into consideration that family history analysis did not reveal the presence of relatives with clinical features of Wiskott-Aldrich syndrome, and DNA analysis of the patient's mother did not disclose any mutation, we could assume that the mutation found in the patient appeared de novo. The severe phenotype of the patient correlated with the presence of an aberrant protein.

In the second case, genetic analysis for the detection of a mutation of WAS gene showed a pathogenic mutation - c.391 G>A (p. E131K) in exon 3 (fig. 1b). Direct sequencing performed in the patient's mother confirmed that she is a heterozygous carrier of the same mutation. Family history analysis revealed the presence of a family member (the maternal uncle) with clinical signs similar to Wiskott Aldrich syndrome, who died in childhood.

In the third case, molecular genetic analysis performed through Sanger sequencing of the WAS gene revealed two mutations - c.57 G>T (p. $\mathrm{Q} 19 \mathrm{H}$ ) in the first exon, and c.136 C>A (p. L46M) in the second exon (fig. 1c). The presumed impact on the patient phenotype was investigated on The Ensembl Variant Effect Predictor and as a result, c.57 G>T (p. Q19H) mutation had a severe phenotypic effect, while the impact of c.136 C >A (p. L46M) mutation was moderate. Considering the patient's age, the WAS clinical score, the immunological picture and the data of the molecular genetic analysis we can suggest the presence of XLT. 


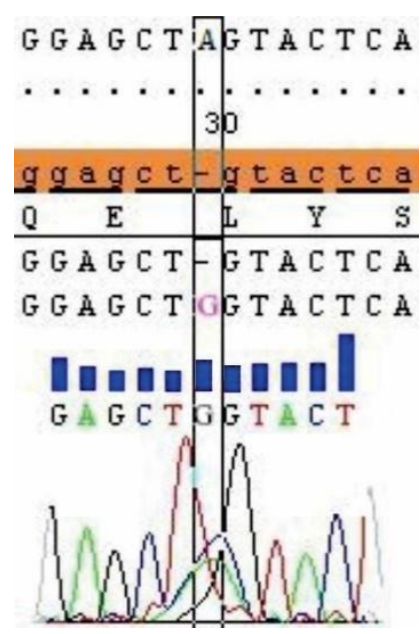

a

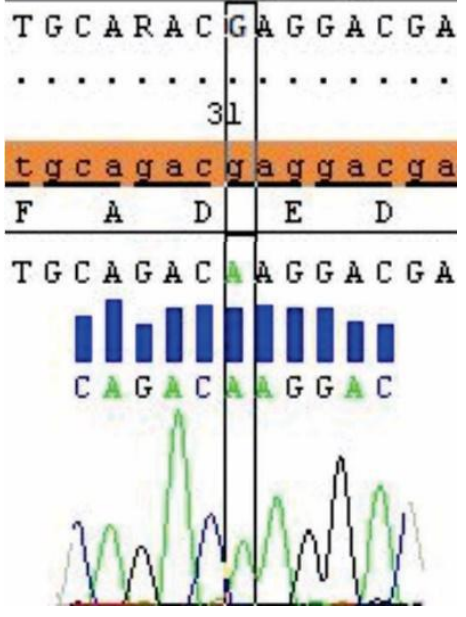

b

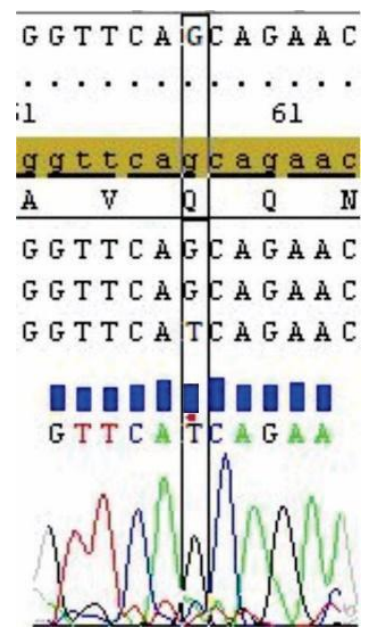

C

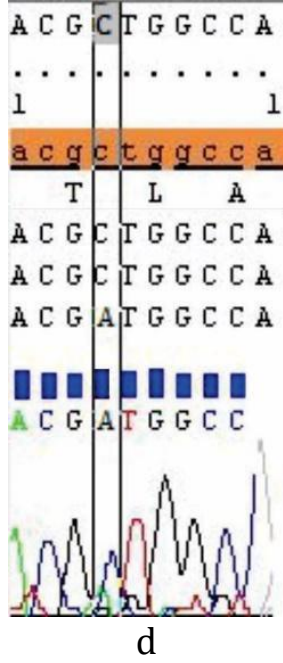

Figure 1. Sequencing identification of mutations in the WAS gene. Wave overlay denotes the presence of the mutation in labeled nucleotide.

a. Mutation c.274-2 A $>$ G located in intron 2 of WAS gene in the first case

b. Mutation c. $391 \mathrm{G}>\mathrm{A}$ located in exon 3 of WAS gene in the second case

c. Mutation c.57 G>T located in exon 1 of WAS gene in the third case

d. Mutation c.136 C>A in exon 3 of WAS gene in the third case

\section{CONCLUSIONS}

1. Due to a wide spectrum of clinical findings, the diagnosis of WAS/XLT should be considered in any male patient presenting with petechiae, bruises, and congenital or early-onset thrombocytopenia associated with small platelet size.

2. Obtaining a definitive and specific molecular diagnosis for a patient with clinically suspected Wiskott-Aldrich syndrome is important because it ensures more effective medical management, allows early access to standard care, avoiding invasive investigations and significant impact on the evolution of the disease.

\section{CONFLICT OF INTERESTS}

The authors declare no conflict of financial or non-financial interests.

\section{REFERENCES}

1. Worth AJ, Thrasher AJ. Current and emerging treatment options for Wiskott-Aldrich syndrome. Expert Review of Clinical Immunology. 2015;11(9):1015-32.

2. Massaad MJ, Ramesh N, Geha RS. Wiskott-Aldrich syndrome: A comprehensive review. Ann NY Acad Sci. 2013;1285:26-43.

3. Mahlaoui N, Pellier I, Mignot C, Jais JP, Bilhou-Nabéra $\mathrm{C}$, et al. Chacteristics and outcome of earlyonset, severe forms of Wiskott-Aldrich syndrome. Blood. 2013;121(9):1510-6.

4. Rivers E, Worth A, Thrasher AJ, Burns SO. How I manage patients with Wiskott Aldrich syndrome. Br J Haematol. 2019;185(4):647-655.

5. Catucci M, Castiello MC, Pala F, Bosticardo M, Villa A. Autoimmunity in wiskott-Aldrich syndrome: an unsolved enigma. Front Immunol. 2012;3:209.

6. Mortaz E, Tabarsi P, Mansouri D, Khosravi A,
Garssen J, et al. Cancers Related to Immunodeficiencies: Update and Perspectives. Front Immunol. 2016;7:365.

7. Yoshimi A, Kamachi Y, Imai K, Watanabe N, Nakadate $\mathrm{H}$, et al. Wiskott-Aldrich syndrome presenting with a clinical picture mimicking juvenile myelomonocytic leukaemia. Pediatr Blood Cancer. 2013;60(5):836-41.

8. Du S, Scuderi R, Malicki DM, Willert J, Bastian J, et al. Hodgkin's and non-Hodgkin's lymphomas occurring in two brothers with Wiskott-Aldrich syndrome and review of the literature. Pediatr Dev Pathol. 2011;14(1):64-70.

9. Kumar S, Xu J, Perkins C, Guo F, Snapper S, et al. Cdc42 regulates neutrophil migration via crosstalk between WASp, CD11b, and microtubules. Blood. 2012;120(17):3563-3574.

10. Boztug K, Dewey RA, Klein C. Development of hematopoietic stem cell gene therapy for 
Wiskott-Aldrich syndrome. Current Opinion in Molecular Therapeutics. 2006;8(5):390-5.

11. Braun CJ, Boztug K, Paruzynski A, Witzel M, Schwarzer A, et al. Gene therapy for Wiskott-Aldrich syndrome-long-term efficacy and genotoxicity. Sci Transl Med. 2014;6(227): 227ra33.

12. Hacein-Bey Abina S, Gaspar HB, Blondeau J, Caccavelli L, Charrier S, et al. Outcomes following gene therapy in patients with severe Wiskott-Aldrich syndrome. JAMA. 2015;313(15):1550-63.

13. Chu J, Henderson L, Lauren A, Myriam M, Frances D. Gene Therapy Using a Self-Inactivating Lentiviral Vector Improves Clinical and Laboratory Manifestations of Wiskott-Aldrich Syndrome. Blood. 2015;126:260-260.

14. Morris EC, Fox T, Chakraverty R, Tendeiro R, Snell K, et al. Gene therapy for Wiskott-Aldrich

Date of receipt of the manuscript: 29/01/2021

Date of acceptance for publication: 03/06/2021

Doina TURCAN, ORCID ID: 0000-0002-8571-0524

Lucia ANDRIES, ORCID ID: 0000-0002-3155-0422

Alexandr DORIF, ORCID ID: 0000-0003-4269-4066

Victoria SACARA, ORCID ID: 0000-0001-9200-0494 syndrome in a severely affected adult. Blood. 2017;130(11):1327-1335.

15. Buchbinder D, Nugent DJ, Fillipovich AH. Wiskott-Aldrich syndrome: diagnosis, current management, and emerging treatments. Appl Clin Genet. 2014;7:55-66.

16. Park SK, Kim CS, Song DK, Kim JY, Choi IJ, et al. A familial case of Wiskott-Aldrich Syndrome with a hotspot mutation in exon 2 of the WAS Gene. J Korean Med Sci. 2007;22(6):998-1001.

17. Jones LN, Lutskiy MI, Cooley J, Kenney DM, Rosen FS, et al. A novel protocol to identify mutations in patients with wiskott-Aldrich syndrome. Blood Cells Mol Dis. 2002;28(3):392-8.

18. He X, Zou R, Zhang B, You Y, Yang Y, et al. Whole Wiskott-Aldrich syndrome protein gene deletion identified by high throughput sequencing. Mol Med Rep. 2017;16(5):6526-6531. 